\title{
Átomos na integração: a aproximação Brasil-Argentina no campo nuclear e a construção do MERCOSUL
}

\section{EVERTON VIEIRAVARGAS*}

Em fins de novembro de 1985, o Presidente do Brasil, José Sarney, e o Presidente da Argentina, Raúl Alfonsín, assinaram a Declaração do Iguaçu, que abriu uma nova página no singular relacionamento entre as duas nações.

A aproximação brasileiro-argentina coincidiu com o relaxamento das tensões entre as Superpotências que levou ao fim da Guerra Fria. Surgiam igualmente duas tendências importantes no plano internacional: a crescente globalizaçãoda economia, fundada na utilização intensiva de tecnologias avançadas, redefinindo a divisão internacional do trabalho; e a consolidação de uma nova agenda internacional, inspirada pelos países industrializados. Destacavam-se, nesta agenda, as medidas para coibir o desenvolvimento, a produção e o armazenamento de armas de destruição em massa, bem como a proliferação nuclear, mormente através de barreiras à transferência de tecnologias sensíveis, isto é, que poderiam ser utilizadas tanto para fins pacíficos quanto com objetivos bélicos.

Para o Brasil e a Argentina essa quadra histórica foi marcada pela restauração da democracia e por esforços para retomar o crescimento econômico, seriamente comprometido pela crise da dívida externa epela instabilidade econômica associada com altas taxas de inflação. Os dois países vinham de uma rivalidade política de várias décadas. A análise dessa rivalidade e de seus contenciosos deu margem à convicção de que o ganho de um país correspondia necessariamente à percepção de perda por parte do outro, tanto em termos materiais, quanto de

Rev. Bras. Polít. Int. 40 (1): 41-74 [1997].

* Diplomata. As opiniões externadas neste artigo são de caráter pessoal e não refletem necessariamente aquelas do Ministério das Relações Exteriores ou do Governo brasileiro. Uma versão preliminar deste trabalho beneficiou-se dos comentários da Professora Norma Breda dos Santos. Naturalmente o conteúdo e a forma finais são de exclusiva responsabilidade do autor. 
poder e prestígio. À sombra dessa percepção germinara a idéia de ameaça recíproca, que seria determinante no esforço para atingir a curto prazo o pleno desenvolvimento nuclear.

A colocação das relações bilaterais num novo patamar implicava, todavia, esforços e medidas para superar suspicácias históricas e para promover uma política de aproximação quelevasse os dois países de uma situação de rivalidade à condição de sócios. Tal condição requeria estreita interação entre os Governos e entre a sociedade civil dos dois países, com importantes repercussões econômicas epolíticas regionais einternacionais.

O presente trabalho tenciona ser uma reflexão sobre a importância da aproximação brasileiro-argentina no campo nuclear como fundamento para a construção de um relacionamento novo que superasse a rivalidade histórica e a irracionalidade consubstanciadanuma competição pelo domínio da técnica nuclear que tinha como uma de suas motivações uma suposta ameaça recíproca à integridade e soberania nacionais. O trabalho se baseará em discursos de líderes e de altos funcionários de um e outro país, bem como em documentos públicos que serviram de base para a construção da nova fase nas relações brasileiroargentinas, a partir de 1985.

O objetivo principal do trabalho émostrar que o processo de aproximação entre Brasil eArgentina, encetado com um desiderato aparentemente econômico, tinha uma dimensão estratégica. As repercussões desse esforço iam além dos interesses bilaterais imediatos para repercutirem na inserção internacional dos dois países num momento de transformações profundas nos planos interno e internacional.

\section{Em busca da racionalidade}

A aproximação entre Brasília e Buenos Aires no terreno da segurança, na segunda metade dos anos 80 e nos anos 90 , teve significado regional, mas ganhou valor imediato no plano bilateral. Neste terreno, concorreu para o abandono do emocionalismo que perpassara as relações Brasil-Argentina no passado recente, agravado pelo contencioso em torno do aproveitamento hidrelétrico do Rio Paraná.

Esta era uma questão estratégica para os dois países. Segundo o Chanceler argentino Carlos Pastor, “a harmonização dos pontos de vista afastaria o risco de desencontros e conflitos permanentes em um ponto de interesse

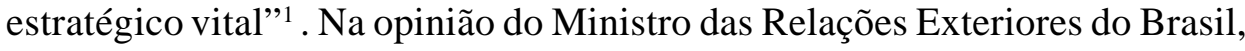


Saraiva Guerreiro, “em um mundo em que se desenham grandes integrações regionais e se caracterizam forças de ação internacional subordinadoras, parecenos necessário que nosso subcontinente supere suas dificuldades e limitações conjunturais, bem como suas quizílias familiares”2 .

Ambos os discursos, pronunciados por ocasião da assinatura do acordo, de 1979, que põe fim à divergência sobre a construção das usinas de Itaipu e de Corpus, deixam implícito o preço da disputa para os interesses de cada país. A ênfase de Pastor no “interesse estratégico” refletia a influência da concepção geopolítica que permeara fortemente a percepção argentina, em particularno meio militar, sobre suas relações exteriores. Guerreiro, ao sublinhar a “integração” e ao se referir às “forças de ação internacional subordinadoras”, deixa claro o interesse brasileiro em procurar um novo relacionamento com os vizinhos sul-americanos, ao mesmo tempo em que, implicitamente, contrapõe essa opção às ações desenvolvidas pelos países mais poderosos da Europa e da América do Norte. A integração nãoé apenas uma linha de Política Externa regional, mas uma carta que cumpria valorizar num cenário internacional onde os interesses globais brasileiros se viam inibidos pela ordem vigente.

As conseqüências da perturbação causada pelo contencioso hidrelétrico e a importância de solucioná-lo ficaram atestados no depoimento do Embaixador Guerreiro: "Sem a eliminação dessa controvérsia, não teria sido possível desenvolver as relações com a Argentina no grau de intimidade e confiança mútua que as caracterizou no Governo Figueiredo e criou as bases para seu incremento progressivo em governos sucessivos. Sem a solução dessa última grande controvérsia do Brasil na região, teria sido impossível a política latinoamericana do Presidente.”3

Outro elemento referencial para a compreensão das relações BrasilArgentina no campo nuclear são as dificuldades financeiras e a ausência de consenso na sociedade brasileira sobre a política nuclear que, em 1980, inibiam o cumprimento do acordo, assinado em 1975, com a Alemanha e que previa a construção de oito centrais nucleares no país além da transferência de tecnologia de enriquecimento de urânio. Esse acordo foi objeto de fortes pressões por parte dos Estados Unidos, tanto em Brasília quanto em Bonn. Neste contexto, cumpre sublinhar que, não obstante as divergências em torno do aproveitamento do Rio Paraná, a Argentina apoiou o Brasil quando das pressões dos Estados Unidos contra o acordo nuclear Brasil-Alemanha ${ }^{4}$. De acordo com o Almirante Castro Madero, ex-Presidente da Comissão Nacional de Energia Atômica(CNEA) da Argentina, "essa atitude abriu o caminho para estabelecer uma efetiva cooperação com o Brasil, que se materializou em 1980"5. 
A posição argentina tinha um precedentehistórico: a atuação conjunta de Brasília e Buenos Aires fora determinante nos resultados das negociações do Tratado de Proscrição das Armas Nucleares na América Latina (Tratado de Tlatelolco), entre 1964 e $1967^{6}$. Ambos haviam também se recusado a ratificar o Tratado de Não-proliferação das Armas Nucleares (TNP), de 1968, por considerálo discriminatório ${ }^{7}$. A atuação coordenada dos dois países no plano multilateral buscava, na ocasião (anos 60), manter abertas vias de suprimento de materiais e tecnologia nucleares, bem como legitimar suas políticas e/ou projetos nacionais no campo nuclear. A colaboração nas negociações de Tlatelolco seria relembrada pelo Chanceler Saraiva Guerreiro em entrevista à imprensa em Buenos Aires, após a assinatura, por ocasião da visita do Presidente João Figueiredo a Buenos Aires, do Acordo de Cooperação entre o Governo da República Federativa do Brasil e o Governo da República Argentina para o Desenvolvimento e Aplicação dos Usos Pacíficos da Energia Nuclear, de maio de 1980. Guerreiro recordou então que "os dois países sempre defenderam um princípio de que deve haver o princípio do direito ao acesso a toda a tecnologia nuclear para fins pacíficos, inclusive o acesso ao explosivo nuclear para o emprego pacífico exclusivamente e sob, evidentemente, as salvaguardas, os controles necessários para que não possa haver um desvio para fins não pacíficos" ${ }^{\text {. }}$

A posição histórica dos dois países em matéria de não-proliferação nuclear decorria de uma opção autonomista quanto à utilização e desenvolvimento da energia atômica. Disto foi reflexo mais evidente o programa autônomo de tecnologia nuclear, desenvolvido pelo Brasil com a intensa participação de suas Forças Armadas, nos anos 70 e começo da década de 80. A resistência americana ao Acordo Nuclear com a Alemanha, a recusa brasileira de aderir ao TNP e a repercussão internacional causada pela detonação de um explosivo nuclear pela Índia, em 1974, fizeram com que aquele programa enfrentasse restrições crescentes ao acesso à tecnologia sensível, impostas pelo regime de não-proliferação estruturado em torno do TNP. Não obstante os diferentes caminhos escolhidos por Brasil eArgentina para desenvolvimento dos respectivos programas nucleares ${ }^{9}$, vários setores tinham potencial para empreendimentos conjuntos. Entre aqueles citam-se pesquisa básica e aplicada, formação de recursos humanos, licenciamento e segurança de instalações, proteção física de material nuclear e pesquisa aplicada para geração de energia núcleo-elétrica, fornecimento de serviços e equipamentos de reatores.

O desenvolvimento autóctone na área nuclear era visto pelo Brasil e pela Argentina como elemento essencial para alcançarem a autonomia tecnológica ${ }^{10}$. Na Argentina, a busca dessa autonomia no terreno nuclear estava claramente 
vinculada à defesa ${ }^{11}$, sobretudo levando-se em conta a existência de problemas fronteiriços com o Chile, com o qual quase chegou a um confronto militar, nos anos 70, por causa do canal de Beagle. Para o Brasil, a capacitação endógena se constituía em instrumento para o desenvolvimento econômico, o qual era elemento central da doutrina de segurança nacional que inspirava o regime militar até a metade dos anos 80. Para seus seguidores, tanto na Argentina quanto no Brasil, o domínio do átomo incrementaria o peso específico do país nos planos continental emundial.

Observa-se, assim, que a política nuclear de cada país tinha por inspiração a consolidação do poder de cada um e o conseqüente aumento de sua segurança. Notava-se também que a competição, acirrada pelo contencioso hidrelétrico nos anos 70, não impedia atitudes cooperativas, como mostram as declarações de Madero e Guerreiro. O enfoque das relações bilaterais a partir de uma perspectiva de poder era consentâneo com o protagonismo de correntes políticas nacionalistas que pregavam um modelo de desenvolvimento no qual o Estado era instrumento central e essencial para o avanço econômico e tecnológico.

Mesmo com a diminuição da influência dos nacionalistas, sobretudo após a derrocada dos regimes militares, a autonomia tecnológica continuou a ser considerada elemento crucial para acelerar as mudanças sociais e econômicas, assegurar a competitividade das economias e aumentar o peso específico dos dois países nos cenários regional einternacional ${ }^{12}$. A propósito, sobre o debate em torno da questão nuclear, vale transcrever o seguinte comentário do Embaixador Marcos Azambuja, que por muitos anos cuidou dos temas de desarmamento no Itamaraty:

“Grande potência, em termos de percepções convencionais, o Brasil nunca soube superar, de forma categórica, a ambigüidade que provoca a opção de dotar-se ou não de uma capacidade nuclear. Embora a posição do Governo tenha sido sempre absolutamente clara e coerente, - a de que o Brasil não persegue essas armas-o sentimento difuso da opinião nacional é contraditório. Identificamse setores que vêem nessas armas, ou minimamente na maestria de como produzilas, o sinal mais prestigioso de que, também nesse campo, temos todos os atributos de grande potência. Outros setores não só não vêem nenhum cenário para o emprego de tais armas, como pressentem que, numa América Latina nuclearizada militarmente, as vantagens permanentes de nosso peso e profundidade seriam desfavoravelmente afetadas pelo nivelador que constituiriam as armas nucleares nas mãos de países próximos”13 .

Em suma, a posse de armamento nuclear pelo Brasil e pela Argentina colocaria esta num patamar de poder semelhante ao do Brasil. Considerando-se 
o poder como uma equação cujas variáveis incluem tanto recursos de ordem geográfica, econômica, social e ambiental, quanto aspectos estratégicos emilitares, pode-se compreender que o potencial de destruição dos artefatos atômicos tornaria praticamente sem valor vantagens naturais do Brasil na região como a dimensão territorial, disponibilidade de recursos naturais, base industrial, etc.

O controle oligopolístico do comércio de bens e tecnologias sensíveis, exercido pelos países industrializados, foi, igualmente, um dos principais motivos para que as autoridades brasileiras e argentinas se engajassem, no início dos anos 80, na cooperação nuclear. O primeiro passo nesse sentido foi o citado acordo com a Argentina para o desenvolvimento e aplicação da energia nuclear, de maio de 1980. O ajuste teve, na verdade, um propósito político maior: celebrado poucos meses após o acordo sobre Itaipu-Corpus, pretendia infirmar a impressão de que os dois países estivessem engajados numa corrida armamentista na área nuclear. Superado o contencioso hidrelétrico, buscavam os dois Governos substituir uma dinâmica de competição por outra de colaboração. Houve a clara intenção de, no preâmbulo do acordo, definir-se o marco político da cooperação: ali se afirmava o propósito de utilização exclusivamente pacífica dos frutos da colaboração, bem como eram repudiados os controles de exportação exercidos pelos países industrializados, ao se declarar que o domínio da tecnologia necessária para a utilização da energia nuclear para fins pacíficos é um direito dos países em desenvolvimento ${ }^{14}$. $\mathrm{O}$ acordo também sublinhava a divergência filosófica dos dois países com o TNP, ao ressaltar a necessidade de impedir a proliferação de armas nucleares através de medidas restritivas não discriminatórias que visassem obter o desarmamento geral e completo sob estrito controle internacional. Com vistas a dar eficácia a essa posição, o artigo IX previa consultas e coordenação de posições entre as Partes sobre "situações de interesse comum que sejam suscitadas no âmbito internacional com relação à aplicação da energia nuclear para fins pacíficos”.

O acordo teve um sentido geral de modo a permitir protocolos específicos que lhe dessem operacionalidade. Na mesma ocasião, foram celebrados um Convênio Básico de Cooperação entre a CNEA e a Comissão Nacional de Energia Nuclear (CNEN), outro entre a CNEA e as Empresas Nucleares Brasileiras (NUCLEBRÁS), e um Protocolo deCooperação Industrial CNEA-NUCLEBRÁS. Estes instrumentos e outros que viessem a ser negociados ao abrigo do acordo dispensariam aprovação dos respectivos Congressos, o que dava ao Executivo maior mobilidade para a condução da cooperação. Um dos resultados mais importantes esperados era a possibilidade de participação da NUCLEBRÁS na construção do terceiro reator nuclear da Argentina, enquanto esta forneceria ao Brasil urânio e outros materiais para combustível nuclear ${ }^{15}$. 
O conflito das Malvinas, em 1982, colocou uma interrogação sobre as perspectivas de evolução da cooperação nuclear ${ }^{16}$, a julgar-se pela intempestividade da ação argentina na disputa com a Grã Bretanha ${ }^{17}$. O eventual retrocesso que poderia ter sido desvendado por esse episódio não se concretizou. Em novembro de 1983, poucos dias após a eleição de Raúl Alfonsín como Presidente (depois de sete anos de regime militar), a Argentina anunciou que lograra enriquecer urânio pelo método de difusão gasosa. Esse anúncio foi objeto de carta do Presidente argentino, General Reynaldo Bignone, ao Presidente Figueiredo, na qual destaca que o desenvolvimento da tecnologia se dera sem qualquer ajuda externa, que a Argentina aderia firmemente à nãoproliferação de armas nucleares. Ressaltava ainda que “o êxito alcançado tem importantes projeções de ordem regional pois constitui um significativo passo para a auto-suficiência da América Latina numa área de tal transcendência no campo dos usos pacíficos da energia nuclear como a do enriquecimento do urânio, com a conseqüente implicação favorável no longo e difícil mas tão desejado processo de integração regional”18.

Dois aspectos cabem ser observados na carta de Bignone: de um lado, a Argentina tinha uma política nuclear cujo objetivo último era afirmá-la como a grande potência latino-americana; e, de outro, o desenvolvimento nuclear era percebido pelas autoridades de Buenos Aires como alavanca para que a Argentina pudesse ter papel preponderante num projeto de integração regional naAmérica Latina, o qual naquele momento era apenas incipiente ecarecia de vontade política dos demais países da região.

O projeto argentino de enriquecimento do urânio fora desenvolvido em segredo, para evitar as pressões e as limitações impostas à transferência de tecnologia pelo Grupo de Supridores Nucleares ${ }^{19}$.Tal projeto envolveu a construção da usina de reprocessamento de urânio de Pilcaniyeu, a qual se afirma que era desconhecida das autoridades brasileiras ${ }^{20}$ e dos próprios serviços de informação ocidentais $^{21}$, que tampouco estava submetida às salvaguardas da Agência Internacional de Energia Atômica (AIEA).

\section{Em busca da confiança mútua}

Arestauração democrática na Argentina, em 1983, e no Brasil, em 1985, abriu possibilidades para maior interesse e escrutínio da opinião pública, em particular da imprensa, sobre as questões nucleares. Para os governos civis da Argentina e do Brasil, a retomada da cooperação preexistente encerrava grande simbolismo, pois implicava assumirem plenamente um setor complexo e sensível, 
onde continuava a existir forte influência e controle militar nos dois países. A democratização trazia consigo maior permeabilidade do sistema político de cada país, tanto devido a fatores internos quanto externos, bem como dava maior legitimidade e exigia maior transparência em suas relações. Ademocracia garantia "senão processos de aproximação mais permanente, pelo menos as bases de um diálogo, mesmo sobre diferenças, que assegura a possibilidade de cooperação" 22 . Exemplo disso foi a proposta do Presidente Raúl Alfonsín, por ocasião da visita do Presidente eleito Tancredo Neves, em 1985, no sentido da realização de inspeções recíprocas nas usinas nucleares. Tancredo teria anuído à sugestão argentina, a qual, entretanto, não teria sido encampada pelo Presidente Sarney ${ }^{23}$, ante a delicadeza do processo de transição democrática no Brasil. Cumpre, entretanto, ter presente que Tancredo e Sarney chegaram à Presidência em condições bastante distintas. Aposse de Sarney, num quadro político e institucional dramático, em decorrência da doença e morte de Tacredo Neves, foi um acontecimento central para a implantação da democracia no Brasil.É lícito, por isso pensar que, ao invés de rejeitar a proposta de Alfonsín, o Presidente Sarney, consciente do momento político, tenha preferido congelar a idéia das inspeções recíprocas para uma ocasião politicamente mais propícia. Aquestão, entretanto, era passível de tratamento no mais alto nível, como se veria com a evolução das tratativas dos dois países em matéria nuclear.

O tema nuclear tinha grande valor político. Contava não só para o esforço de aproximação bilateral mas também para a sinalização à comunidade internacional, em particular para as demais nações latino-americanas, de que as relações entre os dois maiores países do Cone Sul haviam entrado em nova fase. ADeclaração Conjunta sobre Energia Nuclear, outro instrumento assinado pelos Presidentes Sarney e Alfonsín, em Foz do Iguaçu, em novembro de 1985, foi o primeiro passo para a reativação da cooperação bilateral, que definhava especialmente em decorrência da crise da dívida externa, após 1982. Três preocupações ficam patentes na declaração: a importância da tecnologia nuclear para o desenvolvimento dos dois países; o reconhecimento explícito de que ambos enfrentavam dificuldades crescentes no suprimento de equipamentos e materiais nucleares; e a reafirmação dos propósitos exclusivamente pacíficos da colaboração. Para o tratamento desses assuntos em nível operacional, foi criado um Grupo de Trabalho conjunto sob a responsabilidade das chancelarias e integrados por membros das respectivas comissões e empresas nucleares. $\mathrm{O}$ mandato do Grupo reafirmava a continuidade do trabalho que fora iniciado sob a égide do acordo de 1980, através do fomento das relações bilaterais no terreno nuclear; e o esforço pela autonomia tecnológica dos dois países, por meio da promoção do desenvolvimento de tecnologia nuclear. 
Verifica-se na citada Declaração Conjunta sobre Energia Nuclear uma permanência dos conceitos fundamentais que haviam balizado o acordo assinado em 1980. A novidade era o propósito do Grupo de "criar mecanismos que assegurem os superiores interesses da paz, da segurança e do desenvolvimento da região”.

Isto representou uma acomodação do interesse argentino na realização de inspeções recíprocas nas instalações nucleares de cada país. Tomando emprestada a conceituação de Kenneth Waltz, estabeleceu-se uma estrutura com o objetivo de produzir resultados a partir de uma variedade de insumos que afetariam o comportamento de cada país, tanto em suas relações bilaterais quanto em sua interação com os demais países, sobretudo aqueles mais influentes em matéria nuclear. ${ }^{24}$

Na mesma data da assinatura da Declaração Conjunta sobre Política Nuclear, Sarney e Alfonsín firmaram a Declaração do Iguaçu, que estabeleceu o marco político da nova fase da cooperação entre Brasil e Argentina e relançava o processo de integração econômica bilateral. Este era retomado num momento em que os dois países se achavam sufocados pelo problema da dívida externa, aumentavam suas transferências de capital para o exterior e enfrentavam o protecionismo nos mercados internacionais.

A preocupação gerada por essa situação é observada em dois momentos. Na Declaração do Iguaçu (1985), os dois Presidentes concordaram quanto à "urgente necessidade de que a América Latina reforce seu poder de nego-ciação com o resto do mundo, ampliando sua autonomia de decisão e evitando que os países da região continuem vulneráveis aos efeitos de políticas adotadas sem sua participação”. O Presidente Sarney retomaria o tema ante o Congresso argentino, em julho de 1986: "chegamos à conclusão de que, isoladamente, nossos países pouco ou quase nada irão mudar na ordem mundial. Juntos, ao contrário, haveremos de saber influir gradativamente nas decisões internacionais sobre as questões que nos interessam diretamente"25.

Havia a percepção clara de que a crise da dívida extrapolava sua dimensão econômica para se converter num inibidor da própria ação política dos países por ela afetados, agravando a assimetria dos dois países e da América Latina em relação aos países industrializados. As dificuldades econômicas e políticas enfrentadas pelo Brasil e pela Argentina, em meados dos anos 80, colocavam em questão o peso internacional das decisões adotadas pelos respectivos Governos. Ainstabilidade econômica dos dois países teve repercussão muito maior junto aos investidores e instituições internacionais de crédito do que medidas econômicas ou declarações dos dois Governos. A propósito, é oportuno citar 
Arthur Stein, para quem "um Estado pode ser independente no sentido de possuir autonomia decisória, mas ser totalmente dependente no sentido de que suas decisões são inconseqüentes”. ${ }^{26}$ A referência à América Latina na Declaração do Iguaçu é reveladora do desejo de conseguir respaldo dos demais países da região para a aproximação bilateral, bem como para posições defendidas por ambos em forosmultilaterais.

Por ocasião da visita de Sarney a Buenos Aires, em 1986, foram assinadas a Ata para Integração Brasileiro-Argentina e seus protocolos, que estabeleceram o Programa de Integração e Cooperação Econômica BrasilArgentina. Este era um ambicioso projeto político orientado tanto para o desenvolvimento econômico quanto para reforçar a projeção internacional dos dois países. Um de seus pilares era incrementar a autonomia tecnológica em cada país, como se pode notar nos discursos por ocasião da visita do Presidente argentino a Brasília em novembro de 1986.

Segundo Alfonsín, “Aintegração nos permite associar nossos esforços de crescimento ao desenvolvimento de uma estrutura exportadora que nos permita a inserção num mercado internacional altamente competitivo, sobre bases mais sólidas e com maior capacidade de negociação. Para que isto seja possível, devemos incorporar, além da expansão das exportações e do crescimento industrial, um terceiro elemento: a mudança tecnológica. Com efeito, a tecnologia pode ser um poderoso fator de integração regional, possibilitando incrementos na produtividade e na renda; relações cada vez mais estreitas entre os diferentes setores de nossas economias; elevação dos padrões de organização das empresas privadas e públicas e da capacidade gerencial do Estado e a possibilidade de transformar nossas relações internacionais, projetando ao resto do mundo uma realidade social e econômica mais rica. (...) Argentina e Brasil devem avançar na criação de espaço tecnológico comum, que se estenda ao resto da América Latina. Se não o fizermos, vamos perder a possibilidade de exercer com autonomia nossa opção tecnológica, ingressando no século XXI sob o signo da dependência”27.

Para Sarney, “O desafio de nossa história, a meta que inspirou nossa vida desde a independência, foi sem dúvida criar uma verdadeira autonomia para nossos países, reduzir a dependência externa, fazendo das relações internacionais uma opção consciente de nossa soberania, e não um constrangimento marcado pela desigualdade, pelo servilismo. O programa de integração Brasil-Argentina é um marco desse esforço. Com ele, dignifica-se a dimensão externa das nossas economias, ao se criarem bases de interesse recíproco, sem vantagens unilaterais. Com ele, dois povos comprometidos com o desenvolvimento e ansiosos por consolidar conquistas nos campos político, econômico e social, percebem as vantagens da cooperação diante da competição e se lançam na exploração de 
caminhos conjuntos. Com ele finalmente a América Latina encontra uma nova contribuição ao seu indispensável processo de integração, única forma capaz de assegurar ao continente o lugar a que tem direito na história"28 .

A integração é o novo caminho para a inserção internacional dos dois países. O desenvolvimento tecnológico é instrumento de integração, de geração de economias de escala e de independência e de redução do diferencial que separava os dois países e a região dos países centrais. Tanto Sarney quanto Alfonsín vêem-no como veículo para estreitar a colaboração e como instrumento de poder. Os discursos, entretanto, não configuram uma política tecnológica. Não traziam diretrizes que estabelecessem nova orientação para os esforços nacionais na área. Tampouco, tocavam no aspecto da formação de recursos humanos, essencial tanto para a melhoria da competitividade externa dos dois países quanto para a inovação tecnológica. No plano da cooperação nuclear, o Programa de Integração serviria como catalisador para ampliação da cooperação bilateral, inclusive no plano regulatório, de que é exemplo o Protocolo sobre Informação Imediata eAssistência Recíproca em Caso deAcidentes Nucleares e Emergências Radiológicas $^{29}$. Ofereceria também o quadro para aproximar as políticas de segurança dos dois países, revertendo uma histórica percepção de ameaça recíproca.AArgentina foi mais ousada neste particular, como se depreende do discurso de Alfonsín, por ocasião da assinatura dos atos entre Brasil e Argentina durante sua visita a Brasília, em dezembro de 1986: “(...) Creio que estamos em tempo de gerar formas associativas que nos permitam incorporar os elementos do desenvolvimento tecnológico. Neste sentido, ademais, quero destacar a importância de alentar o desenvolvimento nuclear com fins pacíficos como um resultado da cooperação e do esforço comum de nossos técnicos. (...) Igualmente no aspecto militar, nossas Forças Armadas devem seguir programando o desenvolvimento de estudos estratégicos conjuntos, o que implica um avanço substancial nesse campo" ${ }^{30}$.

Asugestão deAlfonsín reflete a busca de uma compensação aos militares, os quais, com a crescente aproximação bilateral no terreno nuclear, viam erodida sua influência num tema crucial para a segurança nacional. A proposta do Presidente argentino também sugere que persistiriam desvios de percepção de parte das Forças Armadas argentinas em relação à capacitação e às intenções de suas homólogas brasileiras. Observe-se, porém, que, se esses desvios de percepção existiam, eles não impediram que os dois Governos fizessem suas escolhas políticas nem determinaram os resultados destas. ${ }^{31}$

Durante a viagem de Sarney à Argentina, em julho de 1987, outro passo importante na colaboração político-estratégica dos dois países foi dado com a 
visita à Usina de Enriquecimento de Urânio de Pilcaniyeu ${ }^{32}$. Esta visita fora precedida de outra, por funcionários argentinos, ao Instituto de Pesquisas Nucleares (IPEN), em dezembro de 1986, onde a Marinha do Brasil realizava pesquisas sobre enriquecimento e reprocessamento de urânio, as quais chegariam à produção de urânio enriquecido em setembro de $1986^{33}$. Tal como Pilcaniyeu, o IPEN não estava submetido às salvaguardas da $\operatorname{AIEA}^{34}$. A visita a Pilcaniyeu foi complementada, em 1988, pela deAlfonsín ao Centro Experimental deAramar, em Iperó $^{35}$, onde se desenvolve a construção de um reator para propulsão de um submarino nuclear. Na ocasião, foi assinada a Declaração de Iperó, que registrou a decisão de incrementar as visitas e intercâmbio de informações, com o objetivo de ampliar o conhecimento recíproco dos respectivos programas nucleares e a transformação do Grupo de Trabalho Conjunto, criado pela Declaração do Iguaçu, em ComitêPermanente. No final de 1988, o Presidente Sarney visitou o Laboratório de Processos Radioquímicos da CNEA, em Ezeiza ${ }^{36}$, destinado à produção de combustível para a usina nuclear de Atucha I e para o reator de água pesada de Embalse, contratado com o Canadá para produção de energia para Córdoba, principal centro industrial argentino fora de Buenos Aires.

Nesta viagem foram assinados o Tratado de Integração, Cooperação e Desenvolvimento entre o Brasil e a Argentina e a Declaração de Ezeiza sobre PolíticaNuclear ${ }^{37}$. O Tratado consolidava num documento juridicamente obrigatório o processo de integração e cooperação econômica, lançado pela Declaração do Iguaçu. ADeclaração de Ezeiza assinalava a decisão dos dois países de desenvolver

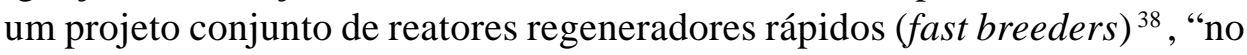
quadro do objetivo comum de garantir a independência energética”. Otratado foi adotado poucas semanas depois de a Assembléia Constituinte brasileira haver aprovado uma nova Constituição que estabelece o controle congressual das atividades nucleares, as quais terão fins exclusivamente pacíficos.

As visitas presidenciais a Pilcaniyeu, Aramar e Ezeiza representaram o ponto alto do processo político encetado pelo Brasil e pela Argentina no campo nuclear. Seu significado foi tanto maior quando se percebe que a idéia deAlfonsín, antes mencionada, de se realizarem inspeções conjuntas nas instalações nucleares não interessou às autoridades brasileiras na época em que foi proposta.

Sendo Brasil e Argentina os dois países mais avançados no campo nuclear naAmérica Latina, as visitas recíprocas às respectivas instalações determinaram uma alteração no conhecimento de cada país sobre a capacitação do outro. A conseqüência prática foi uma progressiva transformação dos interesses brasileiros e argentinos em matéria nuclear, contribuindo para uma cooperação que seria plasmada em tratados internacionais e abrangeria instâncias multilaterais de participação universal, como a AIEA. 


\section{Em busca da transparência}

O ano seguinte, 1989, registraria um dos momentos de inflexão da história da humanidade, com a queda do Muro de Berlim e o fim da Guerra Fria. Para a Argentina e para o Brasil seria também um ano marcado pela chegada ao poder dos Presidentes Menem e Collor. O novo Presidente brasileiro trazia um projeto de maior inserção internacional do país que tinha entre seus principais pontos a abertura e modernização da economia. No bojo desse projeto, estavam a redução dos programas tecnológicos conduzidos pelas Forças Armadas - que passariam a ser controlados pelo poder civil -, e a adesão do Brasil aos regimes de nãoproliferação nuclear. Menem patrocinou um rápido processo de privatização e de desengajamento do Estado, que afetou seriamente os projetos tecnológicos de interesse dos militares. Modificaram-se as posições argentinas em matéria de segurança internacional, inclusive como parte do interesse do novo Governo no estreitamento das relações com os Estados Unidos ${ }^{39}$.

Estas circunstâncias concorreram para a adoção, em nível presidencial, da Declaração sobre Política Nuclear Comum Brasileiro-Argentina, assinada em novembro de 1990, em Foz do Iguaçu. Por ela, seria estabelecido o Sistema Comum de Contabilidade e Controle (SCCC) de aplicação a todas as atividades nucleares dos dois países. Eram igualmente previstas negociações com a AIEA para um acordo conjunto de salvaguardas baseado no SCCC. Os termos da Declaração resultaram do reconhecimento de que, sem providências concretas e permanentes para assegurar transparência nos programas nucleares dos dois países, se incrementariam as restrições internacionais para acesso à tecnologia sensível $^{40}$.

O Sistema Comum de Contabilidade e Controle fora desenvolvido pelo Comitê Permanente Brasileiro-Argentino sobre Política Nuclear e representava o cumprimento do mandato outorgado na Declaração sobre Política Nuclear, de 1985, no sentido de se criarem mecanismos para a manutenção da paz, da segurança e do desenvolvimento na América Latina. Por outro lado, sua implementação dificultaria o desvio das atividades nucleares para programas não submetidos a salvaguardas, como acontecera nos anos 80. A harmonização do SCCC com registros e relatórios submetidos por outros países à Agência, conforme os acordos de salvaguardas vigentes, representava buscar uma via híbrida para o cumprimento das exigências da AIEA sem que os dois países tivessem que aderir ao TNP. Um acordo conjunto de salvaguardas com a AIEA daria legitimidade internacional ao Sistema e reafirmaria os compromissos dos dois países com a não-proliferação. 
Esta via foi pavimentada em duas etapas. A primeira, pelo Acordo BrasilArgentina para o Uso Exclusivamente Pacífico da Energia Nuclear, celebrado em Guadalajara, em 18 de julho de 1991; a segunda, pelo Acordo Quadripartite entre Brasil, Argentina, Agência Brasileiro-Argentina de Contabilidade e Controle (ABACC) e a AIEA, firmado em Viena, em 13 de dezembro de 1991.

OAcordo de Guadalajara afirma o propósito exclusivamente pacífico do uso de todo o material e de todas as instalações nucleares sob jurisdição e controle de cada país. Neste particular, representou um avanço em relação ao Acordo de 1980, cujo artigo VII restringia o compromisso de uso pacífico apenas aos materiais e equipamentos fornecidos no contexto de sua implementação. Argentina e Brasil igualmente assumiram, em 1991, o compromisso de banir completamente as armas nucleares de seu território. Reconheceram, ademais, "a inexistência de distinção técnica entre explosivos nucleares para fins pacíficos e os destinados a emprego militar, abstendo-se, em conse-qüência, de realizar, fomentar ou autorizar (...) ou de participar de qualquer maneira no teste, uso, fabricação, produção ou aquisição, por qualquer meio, de qualquer dispositivo nuclear explosivo, enquanto persista a referida limitação técnica” (artigo I). Tal dispositivo representou o abandono da posição que fora enunciada pelo Chanceler Guerreiro, em 1980, no sentido de que Brasil e Argentina se reservavam o direito a realizarem explosões pacíficas.

Por outro lado, o Acordo estabeleceu como pacífico o uso de energia nuclear para a propulsão de submarinos (artigo III). Esta cláusula, baseada no artigo $5^{\circ}$ do Tratado de Tlatelolco, resguardava as pesquisas em curso pela Marinha brasileira, no Centro de Aramar, orientadas para a construção de um submarino nuclear e, ao mesmo tempo, servia para consolidar o apoio militar a uma política mais aberta em matéria nuclear.

Acriação, peloAcordo de Guadalajara, daAgência Brasileiro-Argentina de Contabilidade e Controle(ABACC), com personalidade jurídica própria, para administrar e aplicar o SCCC, foi uma modalidade inovadora para aplicar salvaguardas, bem como para estabelecer um vínculo com o regime internacional denão-proliferação nuclear.

Por seu turno, o Acordo Quadripartite de Salvaguardas Nucleares estabelece que estas serão aplicadas pelos Estados-Parte "a todos os materiais nucleares em todas as atividades nucleares realizadas dentro de seu território, sob sua jurisdição ou sob seu controle em qualquer lugar, com o objetivo único de assegurar que tais materiais não sejam desviados para aplicação em armas nucleares ou outros dispositivos nucleares explosivos"41. As salvaguardas aplicamse tanto às atividades nucleares realizadas por conta própria quanto àquelas 
resultantes de cooperação internacional ${ }^{42}$. O processo de ratificação do Acordo Quadripartite sofreu pressões contrárias por parte de setores envolvidos com as atividades nucleares, os quais viam-no como mecanismo para sucatear a indústria nuclear brasileira através da importação de tecnologia.

Note-se que sob o Governo Collor, a questão nuclear deixou de ser associada à busca da autonomia tecnológica, como o fora durante o período militar e sob o Governo Sarney. A preocupação maior era com o acesso à tecnologia, e procurava-se um tratamento multilateral mais transparente que legitimasse essa opção. ${ }^{43}$

Outro passo para a consolidação da política nuclear da Argentina e do Brasil foi a proposta dos dois países de emendar o Tratado de Tlatelolco, de 1967. O Brasil o assinara em 1967, ratificando no ano seguinte, mas não dispensara a ratificação ou adesão pelos Estados com possessões na América Latina, nem a assinatura eratificação pelos Estados reconhecidos como potências nucleares de jure ou de facto do Protocolo Adicional I, anexo ao Tratado. ${ }^{44}$ A Argentina somente o ratificou em 1993. As emendas, apresentadas ao México em fevereiro de 1992, relacionavam-se com as responsabilidades da Organização para a Proscrição das Armas Nucleares na América Latina (OPANAL), estabelecida para atuar como Secretaria do Tratado. A Conferência Geral da OPANAL aprovou as emendas em agosto daquele ano.

No Brasil e na Argentina o processo de ratificação foi lento. No Brasil, foi concluído apenas em novembro de 1993, e referia-se unicamente às emendas. Essa demora esteve associada às dificuldades internas relacionadas com o impeachment do Presidente Collor e com as investigações pelo Congresso sobre irregularidades na aprovação do orçamento. Na Argentina, o processo foi mais complexo, uma vez que envolvia a ratificação do Tratado em sua inteireza.

A transparência buscada através desses diferentes acordos refletem uma alteração profunda na visão do Brasil e da Argentina em relação a suas ações nacionais e suas relações com os países detentores de tecnologias avançadas. Verificou-se uma revisão da estratégia de inserção internacional de cada um dos países, com uma disposição para se tornar parte do regime internacional de nãoproliferação e seu conseqüente credenciamento como parceiros confiáveis, sobretudo no que se refere à utilização de tecnologias de duplo uso, isto é, aptas tanto para emprego civil quanto militar. Essa escolha, no caso do Brasil, manteve a posição de não aderir ao TNP, embora a Argentina o tenha feito. Representou ainda o reconhecimento de uma nova tendência na distribuição do poder mundial surgida com a derrocada da União Soviética e dos regimes comunistas na Europa Oriental. Essa tendência, marcada pela abertura econômica e o livre funcionamento 
do mercado, conduziria a uma nova ordem mundial na qual países não engajados nos esforços de não-proliferação seriam tratados como párias internacionais e teriam dificultado seu acesso a bens e serviços baseados nas tecnologias mais modernas. Portanto, as escolhas estratégicas de Brasil e Argentina no terreno nuclear, no início dos anos 90, foram decisões baseadas numa avaliação realista dos rumos do regime de não-proliferação nuclear. O robustecimento desse regime passou ser considerado prioritário pelos países industrializados, sobretudo após a descoberta do avanço logrado pelo Iraque em sua tentativa de adquirir armas nucleares. $\mathrm{O}$ fortalecimento do regime levaria a um crescente estrangulamento do acesso do Brasil e da Argentina a bens e tecnologias avançadas não só para uso nuclear mas também em outros esforços, como nas áreas espacial e de informática.

\section{A aproximação nuclear e a construção do MERCOSUL}

Conforme observado, a negociação nuclear entre Brasil e Argentina foi conjugada com o estabelecimento de novos laços econômico-comerciais entre os dois países. Estas negociações, por tocarem mais diretamente a vida quotidiana dos dois povos, acabaram por ganhar maior espaço nos meios de comunicação. O efeito foi uma minimização da dimensão política da integração econômica bilateral, lançada em 1985 45, bem como da constituição do MERCOSUL deflagrada com o Tratado de Integração, Cooperação e Desenvolvimento, em novembro de 1988, que levou ao Tratado de Assunção, de 1990, que criou formalmente o mercado comum.

A vertente de segurança consubstanciada nos documentos sobre política nuclear e a vertente econômica complementaram-se e retroalimentaram-se. Dificilmente se lograria a harmonização dos interesses econômicos sem uma distensão política que sepultasse a rivalidade entre os dois países no terreno da segurança. Por outro lado, a perspectiva de ganhos concretos num projeto comum de desenvolvimento econômico avalizava as medidas no sentido de se alcançar a transparência necessária para afastar suspeitas mútuas e da comunidade internacional em relação aos desígnios brasileiros e argentinos no terreno nuclear. Cabe recordar que a própria cooperação nuclear prevista no acordo de 1980 tinha no intercâmbio comercial um de seus elementos mais importantes, envolvendo as comissões brasileira e argentina de energia nuclear e a NUCLEBRÁS. Ressalte-se ademais que a ordem seguida pelos dois Governos no terreno nuclear foi um pouco diferente daquela observada nas negociações entre as Superpotências. Enquanto estas elegiam a verificação 
como passo inicial para uma futura cooperação, Brasil e Argentina escolheram os empreendimentos conjuntos como o caminho que levaria às inspeções mútuas e à transparência ${ }^{46}$.

A redemocratização no Brasil e na Argentina, em meados dos anos 80, foi acompanhada de um esgotamento do modelo de industrialização mediante substituição de importações e de fortes pressões no sentido de reduzir a presença doEstado na economia. Adebilidade econômica causada pela crise da dívida e pela inflação requereu, tanto na Argentina quanto no Brasil, ajustes estruturais monitorados pelo Fundo Monetário Internacional, os quais incluíam o fim dos subsídios, a privatização de empresas estatais e a derrubada dos mecanismos de proteção à indústrianacional. Tais ajustes sefaziam através de políticas econômicas recessivas e elevado custo social. Por outro lado, naquela mesma época, as economias industrializadas viviam um período de expansão econômica. Tal crescimento, estimulado pelo emprego de tecnologias avançadas, levouà ampliação do mercado atendido pela produção das grandes empresas, bem como a utilização de componentes, partes e serviços de países com menores custos de produção. Consolidava-se, ainda, a formação de grandes espaços econômicos com o Acordo de Livre Comércio entre os Estados Unidos e o Canadá, de 1987, mais tarde ampliado na negociação do Acordo de Livre Comércio da América do Norte (NAFTA), que incluiu o México e entrou em vigor em 1994. Esses espaços econômicos convivem com novos esquemas de comércio intra-industriais, instrumentalizados em ajustes-acordos entre empresas e/ou governos dos países exportadores, e empresas e/ou governos dos países importadores ${ }^{47}$.

Esse quadro naturalmente impunha ao Brasil e à Argentina encontrar novas formas de inserção econômica. Às pressões para uma abertura da economia - derivadas da globalização da produção e do imperativo de retomar o desenvolvimento após a crise da dívida-correspondia melhorar a competitividade das empresas para o que se faziam necessários capitais e tecnologia.

O processo de integração criaria uma teia de interesses que promovessem não só o intercâmbio comercial e a integração das duas economias, mas também que se constituísse em sustentáculo para as reformas que permitissem a estabilização econômica nos dois países. Como assinalou o Presidente Alfonsín, “o processo de integração não é uma alternativa para a reforma de nossas estruturas econômicas e produtivas. Tais reformas são necessárias, já estão em andamento e terão que ampliar-se no enorme esforço pela modernização de nossos países (...). (...) [O] esforço de integração não é uma tarefa exclusiva dos governos e dos empresários. É, a rigor, um empreendimento que interessa a todos os setores" ${ }^{48}$. 
Como se nota, o discurso de Alfonsín estabelece uma relação entre a agenda interna dos dois países e sua relação bilateral. Ao realçar o interesse geral no processo de integração, reconhece a influência de uma multiplicidade de atores novos, os quais tenderão a refletir na discussão desse processo suas preocupações setoriais. Legitima-se, assim, internamente a integração enquanto projeto político, que sobreviveria às eventuais alternâncias partidárias no poder. Recorde-se, a propósito, que oprocesso de integração deu-senummomento de grande sensibilidade política nos dois países, que pode ser caracterizado em três instâncias. Em primeiro lugar, a Constituição de 1988, estabeleceu a promoção da integração latinoamericana como um dos princípios das relações internacionais do Brasil. ${ }^{49}$ Segundo, aguçava-se a crise do Estado tanto política quanto fiscal. A crise inflacionária e a falta de investimentos afetavam os programas nucleares argentino e brasileiro. O endividamento externo reduzia a capacidade do Estado de impulsionar o processo de acumulação capitalista, bem como de arbitrar conflitos entre os setores modernos e arcaicos da economia. Os dois países passaram igualmente a enfrentar pressões dos países industrializados, sobretudo dosEstados Unidos, em matéria comercial, inclusive com a imposição de sanções a suas exportações para o mercado norte-americano.

Finalmente, em terceiro lugar, o processo de democratização foi elemento essencial na aproximação entre Brasília e Buenos Aires ao implicar maior transparência nas atividades governamentais. Como assinalou Sônia Camargo, "num contexto político autoritário em que o arbítrio, o segredo e a discriminação fazem parte do próprio exercício do poder, dificilmente propostas de cooperação e desenvolvimento regional poderiam encontrar campo de atuação" ${ }^{50}$.

Em suma, a interação das agendas domésticas com os interesses externos dos dois países incrementou a interdependência ${ }^{51}$ entre eles. Os interesses gerados pelo esforço de integração concorreram para alterar o enfoque de cada país, seja quanto à forma e conteúdo de seu respectivo processo de reforma, seja quanto à sua própria experiência de desenvolvimento. O discurso de Alfonsín, há pouco referido, feito à comunidade empresarial do Brasil e da Argentina, ao mencionar a reforma das estruturas produtivas, sinalizava que o processo de integração traria necessariamente a abertura econômica. Esta, naquele momento (1986), já era motivo para pressões dos parceiros industrializados dos dois países e era reivindicada por setores produtivos internos, em especial os voltados para a exportação, que dependiam de insumos importados. Para conviver com essa abertura impunha-se uma adaptação do parque produtivo dos dois países que funcionasse como antídoto ao temor de seu sucateamento que permeava setores importantes do empresariado. 
A maior exposição à concorrência externa promovida pela integração era, portanto, um fenômeno político. Os textos da Ata para Integração e do Tratado de Assunção mostram como se evoluiu de um prudente delineamento do processo de integração para a constatação de sua inevitabilidade, ante as transformações verificadas no cenário internacional.

A Ata para Integração Brasileiro-Argentina, de 1986, assinala que o Programa de Integração “será equilibrado no sentido de que não deve induzir uma especialização das economias em setores específicos; de que deve estimular a integração intra-setorial; de que deve buscar um equilíbrio progressivo, quantitativo e qualitativo, do intercâmbio por grandes setores e por segmentos através da expansão do comércio; propiciará a modernização tecnológica e maior eficiência na alocação de recursos nas duas economias”. O preâmbulo do Tratado de Assunção, celebrado em março de 1991, destaca a “evolução dos acontecimentos internacionais, em especial a formação de grandes espaços econômicos, e a importância de lograr uma adequada inserção internacional para seus países”.

O texto da Ata para Integração Brasileiro-Argentina revela a intenção dos dois Governos de irem além da complementação econômica ou do melhor aproveitamento das vantagens comparativas de cada país. Ao estimular a integração intra-setorial, o equilíbrio do intercâmbio, a modernização tecnológica e a maior eficiência na alocação de recursos, o compromisso subscrito pressupunha uma nova interação entre ambos os Governos, entre estes e o setor privado, bem como entre empresários brasileiros e argentinos. Isso implicava negociações tanto para a formulação de políticas públicas quanto para a escolha de opções para a implementação do acordado. Tais tratativas, porém, não poderiam ficar limitadas a uma visão estreita do intercâmbio bilateral. À luz do Tratado de Assunção deveriam ser orientadas à “adequada inserção internacional” dos sócios do MERCOSUL.

O Tratado representou, assim, uma consolidação da mudança operada nas relações no Cone Sul, a partir da aproximação entre o Brasil e a Argentina, bem como um instrumento para a interação com os demais países e blocos econômicos. Tal esforço somente poderia ser implementado num contexto democrático, isto é, onde houvesse abertura para debates, divergências e alianças.

Por outro lado, ficou à discrição de cada signatário do Tratado definir a “adequada inserção internacional”. Esta, como se tem observado, não se limita ao plano econômico, mas abrange igualmente o político. Neste particular, éútil atentar para as diferentes opções das políticas exteriores do Brasil e da Argentina. É verdade que a vagueza do texto do Tratado de Assunção deixa espaço para 
posições não coincidentes de cada país quanto a temas da agenda internacional. Por outro lado, abre também possibilidades para uniformizar procedimentos em áreas não comerciais, como educação, ou mesmo para aprofundar a colaboração brasileiro-argentina no terreno da segurança ${ }^{52}$.

O processo que levou ao mercado comum revelou também a percepção nos países envolvidos sobre a necessidade de regimes jurídicos e mecanismos institucionais que contribuíssem para a reversão da queda dos investimentos internacionais destinados à América Latina, e em particular a esses países, verificada nos anos 80. Essa retração dos investimentos coincidiu com o surgimento dos blocos econômicos regionais. Um dos propulsores dessa tendência foi o crescimento dos vínculos entre empresas localizadas na região. Estas, ao incrementarem sua escala e poderem investir e se adaptarem tecnologicamente, tiveram possibilidade de expandir suas exportações para os principais mercados mundiais e, no caso das empresas transnacionais, fornecerem insumos e produtos mais baratos para suas matrizes ${ }^{53}$.

Por outro lado, desde o início do processo de integração aumentaram significativamente as trocas entre Brasil e Argentina. Em 1985, o Brasil foi o destino de 5,9\% das exportações argentinas, enquanto que os produtos brasileiros corresponderam a 16\% das importações da Argentina; em 1990, o Brasil absorveu 11,5\% das exportações argentinas, enquanto que 17,6\% das importações da Argentina foram de produtos brasileiros. Esse intercâmbio, visto do lado do Brasil, mostra que, em 1985, a Argentina foi o destino de 2,1\% das exportações brasileiras, enquanto que os produtos argentinos corresponderam a 3,4\% das importações brasileiras; em 1990, as exportações brasileiras permaneceram no mesmo nível, mas as importações subiram para 6,7\%. Em 1994, 20\% das importações da Argentina foram de produtos brasileiros, enquanto que 22,8\% das exportações argentinas foram absorvidos pelo Brasil. Em 1996, os produtos brasileiros corresponderam a 22,4\% das importações argentinas; bens e serviços argentinos significaram 12,7\% das importações brasileiras. Visto de outro ângulo, o Brasil absorveu 26\% das exportações argentinas daquele ano, enquanto que a venda de produtos e serviços brasileiros para a Argentina correspondeu a 10,83\% do total de nossas exportações ${ }^{54}$. Ou seja, a partir de 1994, o Brasil passa a ser o principal destino da exportação de bens argentinos; naquele ano, a Argentina alcançou a condição de segundo mercado para o comércio exterior brasileiro. O livre comércio estabelecido pelo MERCOSUL juntamente com o processo de estabilização da economia brasileira resultaram na forte concentração das exportações argentinas no mercado brasileiro, dando origem ao que alguns setores de opinião argentinos denominam “Brasildependência”. 
O aumento dos fluxos econômicos bilaterais exigiu a harmonização, ainda em curso, de políticas macroeconômicas com o objetivo de atrair investimentos e tecnologia, sobretudo dos países industrializados. As medidas nessa área são especialmente importantes para o aumento da formação de capital - a qual diminuiu sensivelmente no auge da crise da dívida externa podendo ser consideradas como um dos derivativos da maior interdependência entre o Brasil e a Argentina. O processo de formulação dessas medidas é, entretanto, essencialmente político e demanda tanto negociações internas e entre os sócios do MERCOSUL, quanto concessões na esfera interna e no contexto internacional.

A competição global estimula a formação de joint ventures e de alianças estratégicas entre empresas, no contexto das quais o aumento da escala e a redução dos custos de produção juntamente com maior o acesso à tecnologia são elementos fundamentais ${ }^{55}$. Em conseqüência, os dois países ingressaram numa fase de criação de um aparato jurídico-institucional para reger suas atividades econômicas que responda à reivindicação das grandes empresas por normas uniformes para se estabelecerem em seu território.

A liberalização econômica e a revisão do conteúdo e da dimensão da presença do Estado no Brasil e na Argentina criou, como assinala Etel Solingen, uma “coalizão liberalizadora”. A atuação desta foi facilitada com a intenção dos Governos democráticos, sobretudo de Collor e Menem, de reduzir e colocar as atividades nucleares militares sob estrito controle civil ${ }^{56}$. O interesse de ganhos econômicos no processo de integração aumentou a receptividade à alteração nos rumos da política nuclear em cada país ${ }^{57}$. É exemplificativa, a propósito, a declaração do Ministro Domingo Cavallo, pouco antes de assumir a Chancelaria argentina: "Temos tratado de estar presentes e fazer discursos muito principistas em distintos foros internacionais sobre diversos temas, muitos dos quais estão muito distantes de nossa problemática quotidiana, e não temos orientado adequadamente nossa Política Exterior a facilitar a solução dos problemas econômicos e sociais que afetam os argentinos. A nova Política Exterior vai contrastar com esta tendência do passado, ver-nos-á menos presentes na discussão em nível mundial de temas distantes de nossa problemática e encontrar-nos-á preocupados em conseguir que a relação com o resto do mundo facilite a integração econômica da Argentina à economia mundial, à obtenção de capitais e à simplificação dos problemas gravíssimos que afetam nossa gente" ${ }^{\text {58 }}$.

Collor foi ainda mais explícito quanto à relação da política nuclear com os ganhos econômicos ao discursar na Assembléia Geral da ONU, em 1991: “O 
fluxo de bens, serviços e conhecimentos de tecnologias sensíveis é hoje um tema vital. Devemos encontrar fórmulas que conciliem dois interesses básicos: evitar a possibilidade de que tais tecnologias venham a ser utilizadas em armas de destruição em massa, e manter abertos canais de acesso que permitam sua obtenção para fins pacíficos. Esse é um requisito essencial da modernização e da capacitação tecnológica de países como o Brasil”59 .

Os dois discursos mostram uma preocupação imediatista, exemplificada na "solução dos problemas econômicos e sociais que afetam os argentinos" (Cavallo) e na "modernização" (Collor), e o propósito de marcar um rompimento com atitudes ou posições políticas passadas. A idéia do desenvolvimento enquanto processo apoiado por uma forte participação do Estado no setor produtivo cede lugar à noção de modernização, segundo a qual o país deve tirar proveito do que de melhor existe no mercado globalizado. A opção pela modernização foi adotada ainda que a indústria nacional tivesse que ser submetida - como foi o caso no Brasil e na Argentina - a um choque externo que significou a exclusão de várias empresas do mercado, com inegáveis custos sociais. Em suma, a modernização implicou uma reconsideração do desenvolvimento econômico enquanto fator de afirmação da autonomia nacional. Por outro lado, o enfoque pragmático anunciado no discurso do ex-Ministro Cavallo levaria a Argentina a realinhamentos dramáticos em sua Política Exterior, como sua retirada do Movimento Não-Alinhado.

\section{Conclusão}

O projeto de integração Brasil-Argentina extrapolou a dimensão econômico-comercial para se constituir numa parceria estratégica. Elemento essencial dessa parceria, a cooperação nuclear Brasil-Argentina refletiu uma avaliação por parte de cada Governo de que, se de um lado, inexistiam regras unanimemente aceitas e aplicáveis coercitivamente por uma instituição central no campo da não-proliferação (vide as resistências, na época, ao TNP), de outro, havia um movimento crescente, através dos regimes de controle de exportação de tecnologias sensíveis, no sentido de restringir o acesso a elas pelos países não parte desses regimes. Assim, programas nucleares dos dois países não submetidos às salvaguardas da AIEA revelaram-se empecilhos para seus propósitos de acelerar o desenvolvimento tecnológico e incrementar o poder nacional de cada país.

A evolução da atitude dos dois países em relação à política nuclear (mas que pode ser estendida para o campo das tecnologias sensíveis) pode ser 
vista como resultado da eficácia dos regimes de não-proliferação, aliada à constatação das vantagens de implantar um projeto de integração econômica numa macroestrutura internacional marcada pela regionalização e pela globalização. Neste contexto, e como um dos resultados imediatos do relaxamento das tensões entre as Superpotências, a política nuclear deixou de ser vista como elemento para atingir a autonomia tecnológica para se tornar fator de acesso às tecnologias avançadas geradas no exterior e a bens e serviços nelas baseados.

As decisões tomadas no terreno nuclear e no campo econômico criaram uma teia de interesses com o objetivo de se alcançar benefícios não só no terreno da cooperação econômico-comercial mas também em termos da interação do Brasil e da Argentina com outros atores. Assinale-se que esta interação se dá num momento em que dois processos ainda acontecem: em uma região na qual de um lado aumenta o aprofundamento das diferenças entre os países da região decorrente de sua resposta histórica aos desafios econômicos e políticos que enfrentavam em decorrência do autoritarismo e da crise econômica; de outro, em nível mundial, pelo surgimento denovos competidores por investimentos, tecnologia e mercados.

Concebida inicialmente como um esforço bilateral ao qual se somariam no futuro outras nações da América Latina, o processo de integração entre Brasília e Buenos Aires logo envolveu o Uruguai e o Paraguai, países cujas caraterísticas geográficas e econômicas sempre os induziram a políticas pendulares entre o Brasil e a Argentina. Os dividendos econômicos da aproximação entre os últimos não teriam sido possíveis sem a remoção das respectivas suspicácias alimentadas durante décadas e das quais a falta de transparência em seus programas nucleares era conseqüência concreta.

A transformação decorrente dessa aproximação implicou a adoção de políticas de médio e longo prazo, nos planos interno e internacional, bem como intensas negociações entre os participantes. Todavia, a mencionada crise econômica e social, que se abateu sobre os países latino-americanos, nos anos 80 e início dos anos 90, atuou como um inibidor de avanços mais rápidos e profundos na conformação da nova realidade emergente daquela mudança ao exigir políticas pontuais e de curto prazo.

O processo de aproximação entre o Brasil e a Argentina representou clara opção em favor de políticas de colaboração e de coordenação com vistas a resolução respectivamente de dilemas deinteresse comumededilemas relacionados a aversões comuns ${ }^{60}$. Procurou-se mostrar que o discurso utilizado pelos dois países reconheceu a importância da tecnologia e do conhecimento para a 
formulação de tais políticas. A alta tecnologia é vista como essencial para a capacitação das empresas a fim de competirem no mercado mundial. A possibilidade de aplicação dual dessas tecnologias (para fins civis e militares) bem como a importância estratégica de que se reveste seu domínio requerem medidas que protejam seu fluxo. Algumas destas medidas ${ }^{61}$ têm relevância política interna e externa, cuja percepção nem sempre é coincidente. Exemplo disso são a participação nos regimes internacionais de controle de exportações de tecnologias sensíveis e a adoção de regras para proteção de propriedade intelectual. No terreno do conhecimento, a maior transparência dos programas e a colocação sob salvaguarda das instalações nucleares foram condição necessária para que a interação entre os dois países, e destes com a região e com os países industrializados se tornasse mais fluida.

A nova dinâmica do sistema internacional impulsionada pela facilidade das comunicações, pela rapidez dos fluxos financeiros e pela mudança do paradigma tecnológico alterou em profundidade as relações econômicas entre países desenvolvidos e em desenvolvimento. Essas transformações ainda não configuram um desenho definitivo da macroestrutura internacional que substituirá aquela que prevaleceu durante a Guerra Fria. Entretanto, uma de suas conseqüências mais imediatas para os países da América Latina é o abandono das premissas que estiveram na base do processo de substituição de importações, notadamente a participação estatal ${ }^{62}$, como vimos no caso do Brasil e da Argentina.

Outra conseqüência muito importante foi a revisão de posições que se haviam incorporado à política exterior dos dois países, mas que as mudanças ocorridas no cenário internacional ensejaram uma atualização. O exemplo mais eloqüente é a decisão brasileira, em junho de 1997, de solicitar ao Congresso Nacional, autorização para a adesão ao Tratado de Não Proliferação de Armas Nucleares (TNP). No discurso que pronunciou na cerimônia de assinatura da mensagem que encaminha o texto do tratado ao Congresso, o Presidente Fernando Henrique Cardoso recordou que o Brasil, desde a abertura do TNP à assinatura pelos Estados, mantivera uma atitude crítica em relação a ele por considerar seus termos discriminatórios. Reconheceu a correção dessa postura, sobretudo porque a corrida armamentista nuclear representava um descumprimento das obrigações assumidas no tratado pelas potências nucleares. Todavia, os acordos de limitação de armamentos entre os Estados Unidos e a Rússia levaram a cortes importantes em seus respectivos arsenais, ao mesmo tempo em que, com a prorrogação indefinida do TNP, na conferência de revisão de 1995, foi estabelecida uma lista de princípios e objetivos de não proliferação 
e desarmamento nuclear, bem como um mecanismo de exame e revisão semipermanente do cumprimento dos objetivos do tratado. A adesão do Brasil ao tratado se afigura, assim, como elemento para a integração do país nos diversos esforços em favor da não proliferação e como um reforço da posição do país como interlocutor importante no debate de um tema central da agenda internacional.

A colaboração encetada deixou de ser um jogo de soma zero para converter-se num empreendimento em que o ganho de um pode também representar dividendos para o outro. Tais resultados são função do peso de fatores geográficos, econômicos e culturais, influenciados por circunstâncias políticas e sociais. Há, porém, que se ter presente a advertência de Dougherty e Pfaltzgraff de que um relacionamento dessa natureza não significa que estejam resolvidos todos os problemas de conflitos nas relações entre os atores. ${ }^{63}$ É a partir dessa perspectiva que cumpre analisar eventuais diferenças de atitude e de posições entre Brasil e Argentina, seja no campo intraMERCOSUL, seja como resultado de escolhas para sua atuação no contexto global.

Através do programa de integração e do MERCOSUL buscou-se estabelecer uma arquitetura político-jurídica, através de declarações e acordos que permitissem um ajustamento tanto do Brasil quanto da Argentina a essa dinâmica. A rápida evolução do intercâmbio entre os quatro sócios do MERCOSUL criou uma realidade que extrapola o campo econômico e projetase no terreno político, como evidenciado na crise político-institucional de abril de 1996 no Paraguai. Naquela data, os Governos do Brasil, Argentina e Uruguai deixaram claro, ante a ameaça de ruptura de ordem institucional no Paraguai, que a participação no MERCOSUL pressupõe a observância e a promoção da democracia pelos sócios. Essa dimensão política, que começa a despontar na atuação dos quatro, é resultado direto da racionalidade e da confiança mútua inoculadas nas relações Brasil-Argentina, a partir dos anos 80. É lícito esperar que a evolução das relações entre os membros do MERCOSUL os leve a uma crescente coordenação e concertação em torno de temas marcadamente políticos, como forma não só de afiançar os laços econômicos, mas também de reforçar seu diálogo com outros países ou grupos de países e sua atuação em foros internacionais. 


\section{Notas}

1 Ministério das Relações Exteriores, Resenha de Política Exterior do Brasil, n 23, outubro, novembro, dezembro de 1979, "Saraiva Guerreiro: acordo entre Itaipu e Corpus aproxima os povos brasileiro, argentino e paraguaio” p. 89.

2 Idem ib., p. 91.

3 R. Saraiva Guerreiro, Lembranças de um Empregado do Itamaraty, p. 92. A questão do aproveitamento hidrelétrico do Rio Paraná condicionou profundamente a relação entre o Brasil e a Argentina por quase vinte anos. Não é intenção aqui elaborar sobre o tema, o qual está abordado de maneira bastante completa no livro de Christian G. Caubet, As Grandes Manobras de Itaipu. São Paulo: Editora Acadêmica, 1989.

4 Mitchell Riess, Bridled Ambitions: Why Countries Constrain Their Nuclear Capabilities, p. 54.

5 Carlos Castro Madero \& Esteban Tackacs, Política Nuclear Argentina: avance o retroceso?, p. 155

6 John R. Redick, “Latin America’s Emerging Non-Proliferation Consensus”, in: Arms Control Today, March 1994.

7 Esta posição estava relacionada com o fato de o TNP impor obrigações no sentido da não transferência, controle, fabricação, e aquisição de armas nucleares ou outros artefatos explosivos nucleares pelos países considerados militarmente não nucleares, sem impor obrigações aos países militarmente nuclearizados no sentido de eliminarem seus arsenais nucleares.

8 Ministério das Relações Exteriores, Resenha de Política Exterior do Brasil, n 25, abril, maio e junho de 1980, p. 48. Assinale-se que a tecnologia para efetuar uma "explosão pacífica” não difere daquela utilizada para fins militares.

9 O Brasil utilizava a tecnologia do urânio enriquecido enquanto a Argentina a do urânio natural.

10 A questão do acesso à tecnologia e suas repercussões no desenvolvimento do Brasil e na ordem mundial é preocupação histórica da diplomacia brasileira. Em Conferência na Escola Superior de Guerra, em 1958, o Embaixador João Augusto de Araujo Castro assinalava: “A revelação de um progresso tecnológico importante (...) pode levar a mudanças de julgamento sobre o poder relativo das nações. (...) Para o Brasil o caminho mais rápido, mais direto para o Poder Nacional é o próprio caminho de seu desenvolvimento econômico e expansão industrial. (...) Não estamos necessariamente condenados a percorrer todos os estágios de desenvolvimento percorridos por países que se adiantaram a nós na economia e na indústria; a ciência e a tecnologia aplicadas com imaginação e com audácia, na utilização de nossos recursos naturais, poderão levar-nos, num futuro próximo, a uma posição de força no cenário internacional. Não obstante todos os desajustamentos e incertezas de nosso panorama econômico e financeiro, esses objetivos de desenvolvimento - que se confundem com os próprios objetivos 
estratégicos e de Segurança - terão que ser mantidos e ampliados”. João Augusto de Araujo Castro, “O Poder Nacional. Limitações de Ordem Interna e Externa”, in: Rodrigo Amado (org.) Araujo Castro, p. 9.

11 K D Kapur - Nuclear Non-Proliferation Diplomacy: nuclear power programmes in the Third World, p. 115.

12 Vide, a propósito, discursos dos Presidentes Alfonsín e Sarney no almoço oferecido por empresários argentinos e brasileiros em 11.12.86, in: Ministério das Relações Exteriores, Visita do Presidente da Argentina Raúl Alfonsín ao Brasil, 8 a 11 de dezembro de 1986.

13 Marcos Castrioto de Azambuja, “Desarmamento - Posições Brasileiras”, in: Gelson Fonseca Júnior \& Valdemar Carneiro Leão, Temas de Política Externa brasileira, pp. 180/181.

14 Este é um princípio que o Brasil em diferentes ocasiões esgrimiu para defender sua política nuclear. Em 1977, marcado pelas pressões americanas contra o acordo com a Alemanha, o Chanceler Silveira sustentou na abertura do debate geral da Assembléia Geral da ONU que “o verdadeiro sentido da não-proliferação é sustar a disseminação das armas nucleares, e não impedir a difusão da tecnologia nuclear. $\mathrm{O}$ acesso à tecnologia para os usos pacíficos da energia nuclear, atendidos os controles adequados, não deve estar sujeito a restrições discriminatórias”.

15 Vide Convênio de Cooperação entre a CNEN e a CNEA e Protocolo de Cooperação entre a NUCLEBRÁS e a CNEA.

16 Riess, op. cit., p. 54.

17 O Governo brasileiro reafirmou, desde a eclosão do conflito, o apoio do Brasil à soberania argentina sobre as ilhas, que data de 1833, mesmo se a conduta argentina se chocasse com a posição de princípio do Brasil contrária ao uso da força para a resolução de disputas territoriais. Vide “Declaração do Chanceler Saraiva Guerreiro em Nova York, em 2 de abril”, in:, Ministério das Relações Exteriores, Resenha de Política Exterior do Brasil, nº 63, abril, maio, junho de 1982.

18 Ministério das Relações Exteriores, Resenha de Política Exterior do Brasil, n ${ }^{\circ}$ 39, outubro, novembro, dezembro de 1983, p. 122.

19 O Grupo de Supridores Nucleares, também conhecido como Clube de Londres, foi estabelecido em 1974, logo após a explosão nuclear pela Índia. Em dezembro de 1976, o Governo Canadense condicionou sua cooperação nuclear à adesão dos países recipiendários ao TNP ou à aceitação de inspeções por parte da AIEA. Isto teve repercussões importantes na construção, pela Argentina, da usina de reprocessamento de Embalse, a qual estava sendo feita através de um acordo de transferência de tecnologia celebrado com a Atomic Energy Canadian Limited (AECL). Vide Castro Madero e Tackacs, op. cit., p. 56 et passim.

20 Mitchell Riess, op.cit., p. 54. As afirmações de Riess e de Redick devem ser tomadas com alguma cautela. A intensidade da pressão internacional exercida para frear o programa nuclear argentino, não parece consoante com o 
desconhecimento de um fator crítico para o desenvolvimento daquele programa como a usina de Pilcaniyeu.

21 John R. Redick, op. cit., p. 5.

22 Gelson Fonseca Jr., “Aspectos da teoria de Relações Internacionais: notas didáticas”, in: Política Externa, vol. 3, n³ 3, dez./1994, jan.-fev./1995, p. 92.

23 John R. Redick, op. cit., p. 5 e Mitchel Riess, op. cit., p. 55.

24 Kenneth Waltz, Theory of International Politics, pp. 73/74.

25 Ministério das Relações Exteriores, Visita do Presidente José Sarney à República Argentina, p. 18.

26 Arthur Stein, Why Nations Cooperate, página 15.

27 Discurso do Presidente Raul Alfonsín no almoço oferecido por empresários argentinos e brasileiros - 11.12.86, in: Ministério das Relações Exteriores, Visita do Presidente da Argentina Raúl Alfonsín ao Brasil, 8 a 11 de dezembro de 1986, pp. 25-26.

28 Discurso do Presidente José Sarney no almoço oferecido por empresários argentinos e brasileiros - 11.12.86, in: Ministério das Relações Exteriores, Visita do Presidente da Argentina Raúl Alfonsín ao Brasil, 8 a 11 de dezembro de 1986, pp. 31-32.

29 Este protocolo antecipou-se às convenções internacionais sobre Pronta Notificação de Acidentes Nucleares e Assistência Mútua em Caso de Acidente Nuclear ou Emergência Radiológica, celebradas no âmbito da AIEA em setembro de 1986.

30 Discurso do Presidente Alfonsín na Cerimônia de assinatura de Atos BrasilArgentina no Palácio do Planalto 10.12.86, in: Ministério das Relações Exteriores, Visita do Presidente da Argentina Raúl Alfonsín ao Brasil, 8 a 11 de dezembro de 1986, p. 15.

31 Sobre o tema dos desvios de percepção sobre as capacidades e intenções dos atores no plano internacional, vide Arthur Stein, op. cit., página 59.

32 Vide “Declaração Conjunta sobre Política Nuclear”, 17.07.87, in Ministério das Relações Exteriores, Visita do Presidente José Sarney à República Argentina, 15 a 17 de julho de 1987, p. 16.

33 Tal como acontecera quando a Argentina lograra o enriquecimento de urânio em Pilcaniyeu, o Governo Argentino foi previamente informado do êxito alcançado pelo IPEN.

34 Por volta de março de 1988, técnicos argentinos teriam visitado todas as instalações nucleares brasileiras que não se encontravam sob o regime de salvaguardas da AIEA. Mitchell Riess, op. cit., p. 57.

35 Na ocasião o Centro foi inaugurado com a entrada em funcionamento da unidade Almirante Álvaro Alberto da usina de enriquecimento isotópico de urânio.

36 Embora a usina de reprocessamento de Ezeiza estivesse sob salvaguardas da AIEA, por exigência do Canadá, argüía-se que quando funcionasse com plena capacidade, 
seria capaz de, no reprocessamento, extrair plutônio suficiente para construir duas bombas atômicas por ano (Vide Mitchell Riess, op. cit., p. 47). Castro Madero e Esteban Tackacs assinalam, entretanto, que "a Argentina não teve, nem tem como objetivo fabricar uma bomba atômica”; e justificam a busca da capacitação na área de reprocessamento afirmando que "se a Argentina que ter um papel como exportador de tecnologia nuclear, é muito conveniente aparecer nesse mercado tão competitivo, com capacidade em todas as etapas do ciclo combustível” (Vide Castro Madero e Estebán Tackacs, op. cit., pp. 46 e 77).

37 A Declaração de Ezeiza foi a última sobre política nuclear emitida pelos Presidentes Sarney e Alfonsín.

38 Esse tipo de reator utiliza plutônio como combustível e era objeto de pesquisas em alguns países desenvolvidos. Os projetos de construção de reatores regeneradores rápidos acabaram por serem abandonados em todos os países desenvolvidos, a exceção do Japão. As causas para essa decisão estiveram associadas aos custos de construção, bem como as pressões da opinião pública contra a utilização do plutônio como combustível, por causa dos perigos a ele associados, em particular o armazenamento dos rejeitos.

39 Monica Hirst, Security Policies, Democratization and Regional Integration in the Southern Cone, pp. 9-10.

40 Ministério das Relações Exteriores, Resenha de Política Exterior do Brasil, nº 67, outubro, novembro e dezembro de 1990, “Brasil e Argentina assinam Declaração de Política Nuclear: Discurso de Presidente Fernando Collor na cerimônia de assinatura da ‘Declaração sobre Política Nuclear Comum Brasileiro-Argentina’, realizada em Foz do Iguaçu, em 28 de novembro de 1990", p. 42.

41 Acordo entre a República Federativa do Brasil, a República Argentina, a Agência Brasileira de Contabilidade e Controle de Materiais Nucleares (ABACC) e a Agência Internacional de Energia Atômica (AIEA) para Aplicação de Salvaguardas, artigo $1^{\circ}$.

42 Paulo Nogueira Batista, “A Política Externa de Collor: modernização ou retrocesso?”, in: Política Externa, vol. 1, n 4, março de 1993, p. 122.

43 Vide a declaração do Embaixador Marcos Azambuja, quando ocupava a Secretaria Geral de Política Exterior do Itamaraty: “O Brasil deverá empenhar-se crescentemente no sentido de tornar abertos os canais de acesso do País às tecnologias avançadas, através de propostas para tratamento multilateral mais transparente e de medidas de “confidence building” do que são exemplo: os entendimentos na área nuclear entre Brasil e Argentina, in: Conjuntura Internacional: Centros Mundiais de Poder, Conferência proferida durante o Curso de Altos Estudos da Escola de Comando e Estado-Maior da Aeronáutica, e Curso de Altos Estudos de Política e Estratégia da Escola Superior de Guerra, Rio de Janeiro, 23 e 24 de maio de 1991, p. 35.

44 Pelo Protocolo Adicional I, as potências nucleares se comprometem “a aplicar nos territórios que de jure ou de facto estejam os sua responsabilidade internacional, 
compreendidos dentro dos limites da área geográfica estabelecida no Tratado para Proscrição das Armas Nucleares na América Latina, o estatuto de desnuclearização para fins bélicos, que se encontra definido nos artigos $1^{\circ}, 3^{\circ}, 5^{\circ}$ e $13^{\circ}$ do mencionado Tratado."

45 O processo de integração, como assinalado anteriormente, teve como instrumentos fundadores a Declaração do Iguaçu e a Ata para Integração Brasileiro-Argentina e Protocolos.

46 Georges Lamazière \& Roberto Jaguaribe, “Au-delà du raffermissement de la confiance: la coopération nucléaire argentino-brésilienne”, in: Disarmament, Vol. XV, nº 13, 1992.

47 Exemplo disso, foi o contencioso automobilístico entre o Japão e os Estados Unidos que levou ao acordo de 1995, bem como as negociações entre o Japão e a Comunidade Européia, cuja conseqüência foi o comprometimento das empresas japonesas de adotarem voluntariamente medidas específicas para reduzir o superavit comercial japonês.

48 Discurso do Presidente Alfonsín no almoço com empresários brasileiros e argentinos, in: Ministério das Relações Exteriores, Visita do Presidente José Sarneyà Argentina, 28 a 30 de julho de 1986, pp. 30-31.

49 Vide Constituição da Repúblca Federativa do Brasil, art. 4º parágrafo único.

50 Sonia Camargo, “Brasil-Argentina: a integração em questão”, in: Contexto Internacional, Ano 4, nº 9, janeiro/junho de 1989.

51 Sobre a relação entre a interdependência entre os Estados e sua política interna, vide Stanley Hoffmann, "Domestic Politics and Interdependence”, in "Janus and Minerva:Essays in the Theory and Practice of International Politics”, p. 270.

52 Exemplo disso foram as manobras conjuntas entre as Forças Armadas dos dois países em outubro de 1996, bem como o Memorando de Entendimento sobre Consulta e Coordenação firmado entre Brasil e Argentina, por ocasião do encontro entre os Presidentes Fernando Henrique Cardoso e Carlos Menem, em abril de 1997. Este Memorando de Entendimento pode ser visto como a concretização da proposta de Alfonsín, de dezembro de 1986, mencionada anteriormente.

53 Lydia Goldenstein, Repensando a Dependência, pp. 109-111.

54 Fonte:MICT/SECEX/DTIC.

55 Renato Baumann, “Dimensões da Inserção Internacional do Brasil”, in: João Paulo dos Reis Velloso (coord.), MERCOSUL e NAFTA: o Brasil e a integração hemisférica, p. 47.

56 Monica Hirst, op. cit., 1995, p. 10.

57 Etel Solingen, “La Economia Política de la Limitación Nuclear”, in: Revista Occidental, Año 12, Número 1, 1995, p. 52.

58 Declaração ao Clarín, 25 de junho de 1989, citada em José Paradiso, Debates y Trayetoria de la Política Exterior Argentina, p. 197. 
59 Ministério das Relações Exteriores, A Palavra do Brasil nas Nações Unidas 19461995, p. 534.

60 Arthur Stein, op. cit., p. 39.

61 Exemplo dessas medidas é a participação nos regimes plurilaterais de controles de exportação, que procuram disciplinar o comércio de tecnologias de uso duplo. Esses regimes incluem o Missile Technology Control Regime(MTCR), o Nuclear Suppliers Group (NSG), o Grupo da Austrália, na área química; e o Grupo de Wassenaar, que substituiu o Comitê Coordenador Multilateral para Controles de Exportação (COCOM), que funcionou durante a Guerra Fria. A decisão de se juntar esses mecanismos implicou um processo negociador encetado separadamente pelo Brasil e pela Argentina, tendo em vista o diferente grau de avanço tecnológico alcançado por cada um nos setores submetidos aos controles.

62 Lydia Goldenstein, Repensando a Dependência, pp. 105-108.

63 James E. Dougherty e Robert L. Pflatzgraff Jr. “Contending Theories of International Relations: a Comprehensive Survey”, p. 523ç

\section{Bibliografia}

ARAUJO CASTRO, João Augusto de. “O Poder Nacional. Limitações de Ordem Interna e Externa”, in: Rodrigo Amado (org.) Araújo Castro, Brasília: Editora Universidade de Brasília,1982, pp. 3-24.

AZAMBUJA, Marcos Castrioto de. “Desarmamento - Posições Brasileiras”, in: Gelson Fonseca Júnior \& Valdemar Carneiro Leão, Temas de Política Externa brasileira, Brasília: Fundação Alexandre de Gusmão/Editora Ática,1989, pp. 177-193.

. Conjuntura Internacional: Centros Mundiais de Poder, Conferência proferida durante o Curso de Altos Estudos da Escola de Comando e Estado-Maior da Aeronáutica, e Curso de Altos Estudos de Política e Estratégia da Escola Superior de Guerra, Rio de Janeiro, 23 e 24 de maio de 1991.

BAUMANN, Renato. “Dimensões da Inserção Internacional do Brasil”, in: João Paulo dos Reis Velloso (coord.), MERCOSUL e NAFTA: o Brasil e a integração hemisférica, Rio de Janeiro: Livraria José Olympio Editora S.A., 1995, pp. 39-85.

BRASIL, Ministério das Relações Exteriores, Visita do Presidente José Sarneyà Argentina, 28 a 30 de julho de 1986. Brasília: Centro de Documentação, 1986, 141p.

Ministério das Relações Exteriores, Resenha de Política Exterior do Brasil, $\mathrm{n}^{\mathrm{o}}$ 63, abril, maio, junho de 1982.

Ministério das Relações Exteriores, Resenha de Política Exterior do Brasil, $\mathrm{n}^{\mathrm{0}}$ 23, outubro, novembro, dezembro de 1979,

Ministério das Relações Exteriores, Resenha de Política Exterior do Brasil, $\mathrm{n}^{\circ}$ 25, abril, maio e junho de 1980. 
Ministério das Relações Exteriores, Resenha de Política Exterior do Brasil, $\mathrm{n}^{\circ}$ 39, outubro, novembro, dezembro de 1983.

Ministério das Relações Exteriores, Visita do Presidente da Argentina Raúl Alfonsín ao Brasil, 8 a 11 de dezembro de 1986.

Ministério das Relações Exteriores, Visita do Presidente José Sarney à República Argentina, 29 de novembro de 1988, Brasília: Centro de Documentação, 105p.

Ministério das Relações Exteriores, Visita do Presidente da Argentina Raúl Alfonsín ao Brasil, 8 a 11 de dezembro de 1986, Brasília: Centro de Documentação,1987, 103p.

Ministério das Relações Exteriores, Visita do Presidente José Sarney à República Argentina, 15 a 17 de julho de 1987, Brasília: Centro de Documentação, 1988, 62p.

Ministério das Relações Exteriores. Resenha de Política Exterior do Brasil, $\mathrm{n}^{\circ}$ 67, outubro, novembro e dezembro de 1990.

Fundação Alexandre de Gusmão, A Palavra do Brasil nas Nações Unidas 19461995, Brasília: FUNAG,1995, 596p.

CAMARGO, Sonia. Brasil-Argentina: a integração em questão, in: Contexto Internacional, ano 4, $n^{\circ}$ 9, janeiro/junho de 1989, pp. 45-62.

CASTRO MADERO, Carlos \& TACKACS, Esteban. Política Nuclear Argentina: avance o retroceso?. Buenos Aires: El Ateneo, 1991, 249p.

DOUGHERTY, James E. \& PFLATZGRAFF JR., Robert L. Contending Theories of International Relations: a Comprehensive Survey, Second Edition, New York: Harper \& Row, Publishers, 1981, 592p.

FONSECA JR., Gelson. Aspectos da Teoria de Relações Internacionais: notas didáticas, in: Política Externa, vol 3, n³ 3, dez/1994, jan.-fev./1995, pp. 72-100.

GOLDENSTEIN, Lídia. Repensando a Dependência. Rio de Janeiro: Paz e Terra, 1994, 173p.

GUERREIRO, Ramiro Saraiva. Lembranças de um Empregado do Itamaraty. São Paulo: Siciliano, 1992, 204p.

HIRST, Monica. Security Policies, Democratization and Regional Integration in the Southern Cone. (mimeo). Trabalho apresentado no "Inter-american Peace, Security and Democracy Planning Workshop”, organizado pelo “Inter-american Dialogue”, Washington, 6 de setembro de 1995.

HOFFMANN, Stanley. "Domestic Politics and Interdependence”, in: “Janus and Minerva:Essays in the Theory and Practice of International Politics”.Boulder: Westview Press,1987, pp. 268-289.

KAPUR, K D. Nuclear Non-Proliferation Diplomacy: nuclear power programmes in the Third World. New Delhi: Lancers Books, 1993, 394p.

LAMAZIÈRE,Georges \& JAGUARIBE, Roberto. Au-delà du raffermissement de la confiance: la coopération nucléaire argentino-brésilienne, in:Disarmament, Vol. XV, $n^{0} 13$, 1992, pp. 119-136. 
NOGUEIRABATISTA, Paulo. A Política Externa de Collor: modernização ou retrocesso?, in: Política Externa, vol. 1, nº 4, março, abril, maio de 1993, pp. 106-135.

PARADISO, José. Debates y Trayetoria de la Política Exterior Argentina, Buenos Aires: Grupo Editor Latino Americano S.R.L., 1993, 212p.

REDICK, John R. Latin America’s Emerging Non-Proliferation Consensus, in: Arms Control Today, March 1994, pp. 3-9.

RIESS, Mitchell. Bridled Ambitions: why countries constrain their nuclear capabilities. Washington: The Woodrow Wilson Center Press, 1995, 355p.

SOLINGEN, Etel. La Economia Política de la Limitación Nuclear, in: Revista Occidental, Año 12, Número 1, 1995, pp. 43-91.

STEIN, Arthur A. Why Nations Cooperate: circumstance and choice in international relations. Ithaca: Cornell University Press, 1990, 219p.

THORSTENSEN, Vera; NAKANO, Yoshiaki \& LOZARDO, Ernesto. São Paulo e Brasil Frente a um Mundo Dividido em Blocos: o Estado em busca de uma política de comércio externo, in: Política Externa, vol. 3, nº 1, junho, julho, agosto de 1994, pp. 48-83.

WALTZ, Kenneth. Theory of International Politics, Reading, Massachusetts: AddisonWesley Publishing Company, 1979, 251 p.

\section{Resumo}

Este trabalho tenciona ser uma reflexão sobre a importância da aproximação entre o Brasil e a Argentina no campo nuclear, na segunda metade da década de 80 e no início dos anos 90, como fundamento para a construção de um relacionamento novo que suplantou uma rivalidade histórica entre ambos. O processo de aproximação encetado com um propósito aparentemente econômico, tinha uma dimensão estratégica. As repercussões desse esforço iam além dos interesses bilaterais imediatos e se refletiram na busca de uma nova inserção internacional dos dois países, num momento de transformações profundas nos planos interno e internacional. Através do programa de integração BrasilArgentina (que mais tarde também envolveu o Uruguai) e do MERCOSUL buscou-se estabelecer uma arquitetura político-jurídica, que criou uma realidade que extrapola o campo econômico e projeta-se no terreno político.

\section{Abstract}

This paper aims to be a reflection on the importance of the Brazil and Argentina closer relations in the nuclear field, in the late eighties and early 
nineties, as the basis for building a new relationship that replaced a historical rivalry. The aproximation process has begun with apparently economic purposes, but also had a strategic dimension. The repercussions of this effort went beyond immediate bilateral interests, reflected in the search for a new international insertion by both countries, at a time of deep transformations, both internally and internationally. The Brazil-Argentina integration program (that later also involved Uruguay) and MERCOSUL led to the establishment of a political-legal structure that created a reality that goes beyond economics to the political domain.

Palavras-chave: Relações Brasil-Argentina. Política nuclear. Integração regional. Key-words: Brazil-Argentina relationship. Nuclearpolicy. Regional integration. 